\title{
Applied Science in Conference and Display.
}

THERE has been an opportunity during June to take part in two scientific occasions in Germany, both of first rank significance. The Achema Exhibition, opened in Frankfort on June 10, which continued for a fortnight, was primarily a display of laboratory apparatus and all that pertains to the efficiency and well-being of the chemist in his laboratory. A side issue of a most comprehensive character was an exhibition of chemical plant. Concurrently with the exhibition, a meeting of the Verein Deutscher Chemiker was held in Frankfort, and afterwards other more specialised bodies of chemists were in congress there: the habit of centring such annual meetings round an exhibition seems to be spreading. The meeting of the V.D.C. was of course of purely German interest, but a considerable number of British chemists visited the exhibition.

There can never have been a more comprehensive show of aids to chemical manipulation : to one who remembers the then startling innovations provided in Emil Fischer's new laboratory in the Hessischestrasse, Berlin, in 1899 on its opening, the progress is as remarkable as that made in any other branch of chemistry, and one does not recollect before to have had an opportunity of seeing it all summarised as it were under one roof. Comment in detail is impossible and so we pass to the chemical plant section, where undoubtably one of the outstanding exhibits was that of Krupp, designed to show the progress made in the invention of special non-rusting steels or more properly iron. On the principle said to apply to good wine, this exhibit was largely left to speak for itself : it consisted not only of the steels themselves with explanatory literature of real value, but also of all kinds of utensils for the household and for industry, including chemical industry. The exhibit was made by Krupps in conjunction with well-known users of the special VA and VM steels, so that a complete picture was obtainable of the many applications which rustless iron now has. The initial difficulties in working it have been largely overcome, and it appears to be chiefly a question of price which prevents it from being almost universally employed. It should be mentioned that Krupps show household utensils of rustless iron in their own shops in the larger cities of Germany.

of equal interest was the comprehensive exhibit of the famous Metallgesellschaft of Frankfort, who have not hitherto indicated so clearly in how many different fields they are active. As necessitated by the novelty and interest of the exhibits, a very large force of technical experts was in evidence and no visitor was able to complain of lack of attention. Perhaps the greatest interest was evidenced in the display of the Carbo-Union showing the manifold way in which the remarkable absorbent properties of active carbon are being utilised, as, for example, in the stripping of benzol from gas, the recovery of volatile solvents from air, even when very dilute, the purification of water, the dephenolising of effluent from coke ovens, etc. There only remains space to mention the extending use of alloys of silicon with aluminium, which appear to have an ever-widening scope of application as their metallurgy is being better understood. The exhibition was adequately and comfortably housed in permanent buildings such as most Continental towns possess and was regarded by exhibitors and visitors alike as a serious and important occasion.

A night's journey in a sleeper, and we were in Berlin for the Second World Power Congress, attended by nearly 4000 delegates from forty-eight or more countries. The Congress, or at least the official delegates, were welcomed in the Reichstag on the evening of Sunday, June 15, by the highest in the land, when the Earl of Derby, the retiring president, handed over the gong of his office to Dr. Oscar von Miller. The little ceremony was both dignified and imposing, and the human touch supplied by the good wishes for the success of Lord Derby duly bore fruit at Ascot

The official opening took place the next morning in the Kroll Opera House, when, following a short musical introduction, an address of welcome was delivered by Dr. von Miller and responded to by the delegates of the various nationalities, Sir Charles Parsons speaking first on behalf of Great Britain. The speeches were necessarily written and spoken to the microphone, so that the meeting was entirely devoid of personality, oratory, or enthusiasm. At the end we were favoured with more music conducted by a man whose joy, delight, and enthusiasm in what he and his orchestra were giving us was a veritable treat to behold. We must take heed lest in allowing everyone in a large audience to hear what is said we so mechanise what they hear as to make it of no interest. At the subsequent technical meetings, held in two large halls, every seat was provided with earphones and a dial, enabling the hearer to listen either to the original paper or to its translation in either of the three languages-English, French, or German. This arrangement also was only a partial success, in that the effort to speak for the microphone largely destroyed the personality and hence the effect of the orator. At the instance, we believe, of the Americans, the speeches at the World Festival in the evening of June 18 were transmitted by wireless from San Francisco. However attractive the idea, the transmission proved not only inaudible, but also an absolute nuisance, and after a quarter of an hour's patience, the audience ignored it. We have emphasised the terrors of the microphone because we have experienced its devastating effects at banquets at home, where real oratory such as provided by Dr. Nicholas Murray Butler at a recent Pilgrims' gathering is too great a treat to be lightly abandoned to the radio mechanic.

At the technical meetings a very large number of papers were read, discussed, and available in type ; but the real value of the meeting, as always, was the contacts made between workers in different lands with kindred interests. Outstanding, as always in Germany, was the official hospitality. 
Apart from the reception at the Reichstag, the Congress was entertained by Germany, by the State of Prussia, and by the town of Berlin, in addition to a gala night at the Opera and the usual public and private hospitality. Fortunately, the English delegation was not only the largest, but also most thoroughly representative in character, and it played an important part in the deliberations. It was all the more to be regretted that Mr. Dunlop, the prime mover in the Conference, was himself prevented by ill-health from being present.

Naturally, the opportunity was not lost to show the visitors at the great evening festival some of the modern tendencies of Germany. Chief amongst these is the outdoor movement with a minimum of clothing and the cultivation of physical fitness. Most charming displays were given by girls and by young men. Of extraordinary interest was the final display of representatives of the German States in their national costumes and dances: the subordination of Prussia and the accentuation of the Rhine, of the Franks, of the Bavarians, scarcely seemed accidental. The enthusiasm when the president joined his native Bavarians was a fitting climax to a most remarkable evening, which to the knowledgable gave much room for thought, both retrospective and prospective.

Members of the Congress were provided with a quite unusual amount of literature, much of it of a permanentnature, giving information as to the power projects of Germany and of Europe. We have become used to the amazing development of cheap electric power either from coal or from water in the United States or in Canada: what the Congress should bring home is that similar developments are taking place on the Continent. Cheap electricity can do so much for the needs and comfort of mankind that no country of the first rank can afford to let its citizens be without it -it should be available in every village, in very farmhouse, throughout the land, as will soon be the case in France; it should be possible to carry out every power operation on the farm and in the living house, as well as in the factory, by its aid. The presence of so many of our leading electricians at the Congress shows that they are alive to the problems, but we fear the country as a whole fails to realise how far behind Britain is in the use of electricity per capita. We have very little water power, but our engineers are at least capable of emulating the remarkable results achieved at Chicago, where something less than a pound and a half of coal per kilowatt hour is required.

It is often forgotten that the production of electric power is as much a water as a coal problem, about 400 tons of cooling water being required for every ton of coal burnt, so that suitable sites for very large stations are not always easy to find.

The scope of the Congress stretches of course far beyond electric power ; the carbonisation of coal either at high or low temperatures; the problems of oil, its refining and cracking, all come within its scope. In the end the goal is the same, to turn the heat latent in coal or oil, lignite or peat, with the highest degree of efficiency into energy, into power. The transformation in early days was not an easy one, and as represented in percentages highly inefficient. Amazing progress has been made in improving the efficiency; the World Power Congress can but accelerate this. E. F. Arustrong.

\section{Irregularities in the Annual Variation of Temperature in London.*}

$\mathrm{T}$ $\mathrm{HE}$ average temperature of London is lowest about the middle of January and highest towards the end of July, but in any one year. the temperature rises and falls irregularly, and the coldest day may occur in February or March instead of January, the warmest in August or September instead of July. Even when thirty or forty years are combined, some of these irregularities remain, and it is an interesting question whether, as the record is extended, the curve of temperature will tend more and more to a smooth annual variation, or whether certain irregularities are inherent in the climate and will always remain. This question was first examined in detail for Britain by Alexander Buchan, who recorded his conclusions in 1869 as follows :

"Deductions from all observations hitherto made show that... there are certain periods more or less well defined, when the temperature, instead of rising, remains stationary or retrogrades; instead of falling, stops its downward course, or even rises; and at other times falls or rises respectively for a few days at a more accelerated speed than usual." Synopsis of a paper read at the Royal Meteorological Society on
June 18, by Dr. C. E. P. Brooks and S. T. A. Mirrlees, with some June 18 , by Dr. C. E. P. Brooks and
references to the subsequent discussion.

Buchan picked out six cold and three warm periods, as follows :

Cold Periods.
1. February 7-14
2. April 11-14
3. May 9-14
4. June 29-July 4
5. August 6-11
6. November 6-13

Buchan's work was based in the first place on data for Scotland about 1860, but his results have been tacitly assumed to apply over the whole of the British Isles, and the 'Buchan cold and warm spells' have attained some celebrity. A repetition of the investigation seemed to be called for, using a long series of records for London.

Daily means of temperature at Kew Observatory based on hourly readings were formed for the two nearly equal intervals 1871 to 1900 and 1901 to 1929. These showed many small irregularities, and as warm and cold 'spells' were being sought rather than individual days, it seemed advisable to smooth the data. This was done by forming overlapping five-day means, for example, January $1-5,2-6$, etc., each five-day mean being entered against the middle day. The two curves obtained 